\title{
Perspectivist Chicano Studies, 1970-1985
}

\author{
Michael Soldatenko' \\ Santa Monica College
}

\begin{abstract}
This essay examine the development and failure of Perspectivist Chicano Studies. By the late 1960s Chicano(a) academics constructed several views of Chicano Studies. Not all Chicanos(as) followed EI Plan de Santa Barbara nor interpreted it in the same manner; several expressions of Chicano Studies existed. This essay traces one such articulation through the writings of Romano and Carranza who develop perspectivism. In the academy the writings of Rodriguez and Rocco manifest Perspectivist Chicano Studies. Moreover in the writings of Atencio and the activists of Hijos del sol we encounter a non-academic expression of this view of Chicano Studies. The essay ends with the failure of Perspectivist Chicano Studies to challenge the rise of an empirical driven Chicano Studies.
\end{abstract}

The on-campus activism by Chicano and Chicana studies produced a plethora of intellectual styles of knowing in the late 1960s and early 1970 s. The Chicano(a) student movements, together with the boom in Chicano Studies ${ }^{2}$ programs, led to an explosion of academic production. While many intellectuals followed the political and intellectual agenda established by EI Plan de Santa Barbara, EI Plan was not the only possible option for Chicanos(as) in the academy. The activism that led to the formulation of El Plan also brought to life other configurations of Chicano intellectual work. There was a time, in other words, when multiple Chicano Studies coexisted with several possible options of bridging Chicano Studies and the academy. This chaotic and complex period witnessed the construction of many styles of Chicano Studies that expressed distinct intellectual approaches and programs-formulated in a hostile, aggressive, and turbulent environment. In this essay I will trace one such tradition: "Perspectivist Chicano Studies."

It is difficult to define Perspectivist Chicano Studies. This vision lost the struggle to present itself as the legitimate interpretation of Chicano Studies. By the late 1970s and early 1980s, Perspectivist Chicano Stud- 
ies became an increasingly peripheral and fragmented intellectual agenda surviving in corners of some non-research teaching institutions, alternative educational institutions, the arts, and certain community organizations. As victorious "Empirical Chicano Studies" settled in the prestigious institutions and its works were transformed into the canon of Chicano Studies, the perspectivist writers were progressively pushed toward peripheral journals or self-publication. As the "empirics" further disciplined the field, they apprehended Perspectivist Chicano Studies as at best a quaint romantic vision and at worst as irrational and apolitical. Because of the success of the empirics, Perspectivist Chicano Studies never had the opportunity to mature into a concise intellectual style, its practitioners often being isolated. This lack of success allowed enormous variation among perspectivist writing as well as off key, if not contradictory, expressions of this style.

Given these caveats, nevertheless, I believe I can still provide a working definition for this intellectual style. Perspectivists centered their work on formulating a Chicano standpoint that arose from their experience in the US. Critical of social science research and skeptical of academic work, these scholars sought to establish an oppositional epistemology rooted in the process of Chicano(a) identity formation.

To understand this perspectivist position, we need to turn to Chicano(a) early endeavors to understand Mexican thought. In looking over early syllabi in Chicano Studies courses (1968-1975) one can see the influence of Patrick Romanell's Making of the Mexican Mind, Samuel Ramos' Profile of Man and Culture in Mexico, and Octavio Paz's The Labyrinth of Solitude. These texts provided Chicanos(as) with a particular interpretation of the "Mexican character" and, more importantly, with a theoretical/philosophical vision. In particular Romanell's and Ramos' texts introduced Chicanos(as) to the perspectivism of Jose Ortega $y$ Gasset: "a theory of knowledge in 'culturalist' dress." ${ }^{4}$ As Romanell defines this view:

Perspectivism, in brief, is the theory which holds that since reality is composed, like a landscape, of an 'infinite number of perspectives,' some of which we come to know through the 'selective' medium of 'vital reason,' therefore, reality does not possess in itself, 'independently of the point of view from which it is observed, a physiognomy of its own.'5

Therefore perspectives constitute reality; truths are points of view, all equally authentic and true. "[T]ruth and error, like life and death, are matters of history and history is a matter of perspectives." ${ }^{6}$ What makes Ortega y Gasset's position different from Protagoras' view that each man is the measure of all things, Romanell continues, is the need to restore individuals their national perspectives-a philosophy of culture 
(Kulturphilosoph). Mexican thinkers, Romanell concludes, found this intellectual vision more acceptable than the various manifestations of rationalism. They found "a 'norm' applicable to Mexico in Ortega's pivotal idea: "Yo soy yo y mi circumstancia." Interestingly, in these texts, I believe, we also uncover a key part of the intellectual origins of Chicano cultural nationalism and Chicanismo. Chicano(a) readings of these texts gave them a particular reading of Mexican thought, reinforcing the supposed continuity between the "Chicano mind" and the "Mexican mind," and provided an intellectual vision of Chicano politics. Perspectivism's reference to one's circumstances fitted well with Chicano calls for a link between community and university. Readings for these texts further endowed Chicanos(as) with a theory of being and knowledge that could function as the ground for Chicano Studies. The formation of this vision of Chicano Studies is what I trace in the following pages.

\section{INTRODUCTION}

Octavio Romano's writings provide the link between Mexican perspectivism and the formulation of Perspectivist Chicano studies. While Romano's essay influenced most, if not all, early Chicano thinkers, the particular solution that Romano presents to the production of knowledge had the greatest influence on Chicano(s) perspectivist thinkers. By briefly tracing Romano's argument we can visualize the genesis of this style. Romano depicts social scientists as scholars who have translated the Mexican American into a masochistic, passive, irrational, fatalistic un-American. Social scientists use concepts, such as "traditional culture," that distort the realities of Mexican American communities by presenting them as ahistorical peoples. Consequently, Romano points out, these scholars engage in "social science fiction." In contrast Romano formulates an intellectual framework so as to overturn the social scientists' myths and begin a real exploration of the Mexican American experience. This approach starts by restoring Mexican American history. From this history Mexican Americans can learn that they carry four distinct ideological trends: indianist philosophy, historical confrontationism, the philosophy of the mestizo, and the immigrant experience. ${ }^{8}$ These tendencies reveal the Chicano as an historical and intellectual actor and dismiss the social scientists' endeavor to construct a "true" Mexican or Chicano type. This experience base, Romano continues, is within reach of any Chicano; he simply needs to converse "with los viejos in the barrios." "The picture that emerged from the dialogue with the viejitos was one of constant struggle." 9 This is not the story that social scientists want to depict.

But Romano's argument does not stop here; he moves beyond critique and memory. Initially Romano criticizes individual works, scholars, and methodologies; now he starts to question the field of social 
science. In "Social Science, Objectivity, and the Chicanos" Romano historicizes "objectivity" in order to subvert its meaning, and more importantly, undercut its use by social scientists. Objectivity, he notes, demands the separation of events, phenomena, and ideas from personal self-consciousness. This empirical project lies at the center of social science and the humanities. This dualism provides methodological and conceptual legitimacy to social science; it assumes a unity between the laws governing the physical universe and those that govern human behavior. For this reason social science presents itself as valuefree, culture-free, and tradition-free-as science. Romano wants us to reject this concept of objectivity given its insistence on the separation of mind and body. Consequently we must also set aside social science studies. Instead Romano proposes to start Chicano research from the perspective of the Chicano subject. Chicano Studies must begin from the "self-image" of the Chicano scholar. Given the failure of objectivity and social science, Chicanos needs to reclaim and rewrite themselves. ${ }^{10}$ If this self-image is rejected by non-Chicano social scientists, then in effect, they will have rejected summarily the rationality of the Chicano. ${ }^{11}$ As the Chicano becomes subject, social science fades. In this way, Romano alters the relationship between Chicano scholarship, knowledge, and the academy.

Romano, I believe, formulates a perspectivist epistemology in contrast to social science empiricism. This provides a starting point for many Chicano(a) intellectuals that sought an alternative to social science. Unfortunately, Romano himself does not follow up on his argument. We see his work move increasingly toward the arts. While Romano's interests may have always been in the arts, this shift is facilitated by his inability to develop a standpoint position as a methodological tool grounded in the particularities of U.S. political, economic, and societal contradictions.

Though Romano maynot have followed through on his epistemic break, his essays provide Chicanos and Chicanas with the intellectual tools in their battle with social scientists' methods, methodologies, and epistemologies. His intellectual vision allows a radical positioning of Chicanos(as) in relationship to the engrossing academic project. He presents a Chicano perspective that supports a Chicano Studies that could avoid the pitfalls of social science. Thus he articulates, though not as clearly as he could, a non-disciplinary non-social science Chicano Studies that could survive, albeit always peripheral and questionable, in the university. Unfortunately Romano did not pursue this discussion; he remains a critic of social science without developing an epistemological and methodological alternative.

Some Chicano(a) scholars felt that university students, faculty, and staff needed an articulated plan for political action that did not find expression in Romano's writing. This endeavor led to the formulation of 
Empirical Chicano Studies. Empiric scholars saw the battle for Chicano Studies in two stages. The first and most important stage was the institutionalization of all university programs that dealt with Chicanos(as) under Chicano control. They visualized these programs as part of the overall political struggle for Chicano self-determination. The second concern of these scholars was to develop objective methods that could provide students with knowledge of their cultural, historical, and socioeconomic inheritance. These curricular concerns supplemented the institution-building process. As Rochin notes Chicanos saw the university "as a vital institutional instrument of change." 12

In 1969 a group of over a hundred students, faculty, staff, administrators, and community folk came together at Santa Barbara to devise a blueprint for Chicano self-determination and liberation-EI Plan de Santa Barbara. At the heart of their call for action is using the academy as a weapon in the emancipation of the Chicano community. Juan Gomez-Quinones explains the political vision of his agenda through a reading of Lenin:

Lenin did not condemn academic reform activity per se. With his unfailing good sense he saw academic protest as good a place as any to start the actions on campus as part of a wider effort for political mobilization. ${ }^{13}$

To implement this political strategy, El Plan presents a schema of institution building in which Chicanos would both control their programs and retain relative autonomy in the institution. Chicano power could then be achieved on campus and university resources directed to the Chicano community. The organized Chicano students and community stand at the center of this political task. In this way, Chicano community interests can be established at the university. ${ }^{14}$

Reynold Macias, Juan Gomez-Quinones and Raymond Castro, building on El Plan, formulate a program to structure Chicano Studies as an academic field by establishing its philosophy and objectives. Chicano Studies, they argue, should be institutionalized within the university where it should be given sufficient latitude to achieve the goals of self-determination and self-definition.

Chicano Studies, then, in all disciplines and in all areas involve re-definition, re-interpretation, and most importantly, a premise for the above two, ... a change of framework. It in effect affirms a counter culture that is authentically Chicano and universal. ${ }^{15}$

In order to achieve this goal, they want to integrate Chicano Studies into the university by developing a system of institutional units such as stu- 
dent services, community development, research and the like. This demands the recruitment of Chicano students, faculty and staff, the development of a program of formal study of Chicano culture and history, the development of support programs, research programs, publication programs, and cultural/social centers in the community. Chicano Studies must be made part of the university at all levels if it is to have any real impact; furthermore these units must be under Chicano control.

These thinkers further argue that this process of institutionalization also requires a different philosophy of education. The current framework of cultural pluralism, they emphasize, leads to an ethnocentric education. This philosophy creates institutions that are not geared to the needs of Chicanos and their community. Given this situation, students need a Chicano philosophy of education; this framework would provide students with a relevant education and prepare them for community service resulting in needed political, social, and economic change. Students will develop their leadership skills especially in regard to organizing. Thus their vision of a Chicano philosophy flows from their politics of institutionalization. The Chicano philosophy of education and the institutionalization of Chicano Studies will result in students who will partake in the "reformulation of knowledge in relation to the Chicano" and the transformation of the Chicano's position vis-a-vis the "gabacho system." 16

What they left unclear is their characterization of knowledge. What does knowledge production mean within newly institutionalized Chicano Studies? Is it any different from any other field? How does it compare to academic knowledge? Their response leaves much to be desired: "A Chicano student must know how to locate the knowledge that he may need for pursuing action." 17 They assume a neutral objective process in knowledge formation; they accept an empiric and instrumentalist perspective of American academic knowledge. They believe that institutional control will have direct impact on the production of knowledge. They returned to the positivism and scientism that the Mexican followers of Ortega y Gasset found unacceptable. This supposition continues to haunt Chicano Studies today. ${ }^{18}$

\section{Chicanismo and Perspectivist Chicano Studies}

As more campuses established Chicano Studies programs, some activists were increasingly concerned about the character and direction of these programs. This was especially true in regard to the academic side of these programs. What made a Chicano Studies course any different from any other course? What should the goals of the curriculum be? To respond that these courses dealt with the "Chicano experience," some felt, was insufficient: Chicano Studies also had to provide a vision of life; organization building and institutionalization was found wanting. Chicano Studies had to deal with existence. An ex- 
ample is Thomas Martinez's essay, presented at the Chicano Studies Summer Institute in 1970 and later appearing in Epoca.

Chicano Studies programs, Martinez observes, need to foster "a philosophy of living - an alternative set of values to those now persisting in Anglo-American society." ${ }^{19}$ Fortunately Chicanos possess such an alternative philosophy-Chicanismo. While we should not read Chicanismo as simply a reaction to Anglo society, it does manifest a dissatisfaction with "Anglo-white values." Anglo values emphasize material achievement to prove self-worth. Chicanismo, in contrast, is the antithesis of this value system. Chicanismo, according to Martinez, is about spirituality, honest self-examination, a complete love of life, and consciousness of the here and now. Chicanismo is a variant of the larger humanist tradition missing from mainstream America.

Chicano Studies, Martinez adds, is not about social science alone but about existence. 'It is the 'inner' life that is most important in defining worth of self and others." ${ }^{20}$ The problem with the university is not only academic; it is about human behavior, responsibility, values, ethics-about humanism. "Do not allow the administrative responsibilities for programs to dictate the development of a 'bureaucratic personality' to the exclusion of Chicanismo values."21 Chicano Studies must continually preserve and promote this humanism (i.e. Chicanismo) to resist the bureaucratic mentality of the academy. "There is a humanistic tradition inherent in the Chicano culture. It embodies an identification with all that is living." 22 Or as Medina writes, the "existential perception of life is that it could be human being-centered."23

According to Gomez-Quinones, a variety of political and intellectual communities utilized Chicanismo throughout the early period of the Chicano movement. ${ }^{24}$ For many this spirit embodies the core values of all those struggles with the dominant Anglo society: "Chicanismo [is] the ideology of El Movimiento and of Mexican American politics."25 Chicanismo draws inspiration from struggles outside the US and the Chicano experience, such as the Cuban Revolution and Black Power. It links various Chicano struggles with the diversity of academic Chicano Studies. For others, however, Chicanismo is also about cultural resistance, humanism, and revolutionary praxis. "Chicanismo is at once an ideology and a cultural expression...the main tenants of Chicanismo are humanism and self-determination. It calls for the humanity of man through revolution." 26

For this reason, Chicanismo connects to carnalismo; both are rooted in respect.

Carnalismo is a brotherhood, it is an understanding and an awareness of the concepts-love, nature, peace, culture, and destiny, that allows this brotherhood to evolve....Carnalismo is the philosophy of the Mexican as he transcends political and social philosophies into humanistic terms. ${ }^{27}$ 
Chicanismo therefore can be seen as "a way of life, a spiritual calling, a love, a respect, and a duty." The Chicano, moved by social injustice, sees it as his duty to fight wrongs: "A Chicano does not wag his tongue about injustice and wrong. He acts more than he speaks." ${ }^{28}$ In this way, he challenges the dominant belief system and attempts to reconstruct the Mexican American. This reconstruction begins with an appeal to pride in a common history, culture, and "race." Chicanismo attempts to redefine the Mexican's identity on the basis not of class, generation, or area of residence but on a unique and shared experience in the United States."29 This manifests itself in the politics of cultural nationalism and patriarchy..$^{30}$

I do not want to reduce Chicanismo to Perspectivist Chicano Studies or vice versa. Chicanismo permeated all Chicano politics in the late 1960 s and 1970s. Therefore the languages of Chicanismo can be found in most expressions of Chicano Studies. However the vision of a living Chicano culture (Ramos' "cultura viviente") as the central core of Chicano Studies, I believe, is what makes Perspectivist Chicano Studies so distinct from Empirical Chicano Studies. This reflects the difference of defining Chicanismo as a political expression or as a philosophy.

\section{Chicanismo As Philosophy}

Eliu Carranza formulates a philosophic framework for Chicano(a) perspectivism. Like Romano, he begins with a return to Chicanos' heritage and values. "The Mexican American has had to return to his own, his parent's, his grandparent's values. This is what has made the movimiento a reality." ${ }^{31}$ But a simple return is not sufficient. Carranza demands that the Chicano honestly confront his past. Not all that is part of this heritage is good; some must be cast aside. Once the Chicano accomplishes his self-evaluation, he can boldly move into new directions, holding fast to the privilege of self-determination. In this way, he makes himself into a human being. "Our point of departure is self-determination; our strategy is confrontation and refutation; our enemy is racism; our goal is Carnalismo-flesh of my flesh, bone of my bone, and blood of my blood. This is the essence of Chicano humanism." 32 The Chicano is reborn with the spirit of freedom, truth, and life. For this reason, Carranza believes that this marks the start of a "cultural revolution" by which the Chicano comes into being significantly changing his world view. Chicanismo, Carranza concludes, holds the key for the new humanism that can save the U.S.

This "cultural revolution" parallels an analogous transformation of education. Through this "new" education, the Chicano will decolonize and liberate his mind permitting him to see himself in the face of his fellow. The Mexican American mind will free itself by establishing free 
universities, Chicano institutes, or autonomous schools of Mexican American studies that will research, articulate, publish, and disseminate knowledge of the Mexican American. Liberating knowledge, Carranza implies, is not legitimated by social science; this can only come about by Chicanismo.

In a later edition Carranza reacts to the increasing instrumentalization of Chicano Studies; he is reacting to the rise of Empirical Chicano Studies. While he accepts traditionally defined functions of Chicano Studies, such as opposing prejudice and stereotyping as well as serving the community, he also adds that Chicano Studies must help the Chicano to "know himself in his world." The Chicano must dare to be a human being; he must be the agent of his existence and its meaning. Unless the Chicano centers himself in the world as subject, he will be engulfed. "[U]nless Mexican American Studies commits itself to new approaches it, like other departments, will find itself readily assimilated into the existing structure as one more department among departments...." ${ }^{33}$ To play with social science without Chicano self determination established is to ask for co-optation.

Another reason that may account for the term's [Chicanismo] passing may be a predilection of Chicanos toward the social sciences route to knowledge, in effect, to the neglect of the humanities and philosophy. Thus, Chicanismo [is] taken to refer not to the world view which it constituted, but to a group 'life style,' deemed suitable for the statistical approach to truth via the social sciences. ${ }^{37}$

It is only humanism that can resist this instrumentalization.

Chicano Studies, dominated by empiricism, Carranza concludes, erases the Chicano. "The search for the essence of the Chicano and the super-Chicano...[has] become a search for what [is] not there..." ${ }^{35}$ Empirically driven Chicano Studies reduces the Chicano and his problem to one or two basic perspectives: the colonial or Marxist model is not sufficient. Rather, we need to understand the Chicano through multiple perspectives.

For the Chicano Movement is in many respects a coming together of many often diverse points of view. The language of each point of view generates a different perspective concerning our situation, our problems, and the kind of solutions called for. Each perspective is important as one among others. ${ }^{36}$

The priests of the movement," Carranza laments, reject this call for perspectivism; they only accept one model of understanding the world. 
Ethnic Studies Review Vol. 19, No. $2 \& 3$

Carranza wants us to recognize our multiple perspectives. Only from one's particular perspective, Carranza emphasizes, can one truly become an "active creative participant."

"These considerations led me to the proposition that many Mexican-Americans were in possession of the truth of their condition, but had either suppressed it or had learned to ignore it..." ${ }^{37}$

To create an understanding of the world, one must start with one's Chicano experience, with one's being in the world. In this way we can break the "grinding alienation of prejudice and hatred" and everyone can then develop their aspirations. Then we can explore enchantment, life, death, meaning, and love-resulting in Chicano liberation.

To challenge the victorious Empirical Chicano Studies, Carranza proposes Chicanismo as a world-view.

The need for a conceptualization of reality from the Chicano perspective has never been a more necessary undertaking than at this time. The fact it has never been accomplished heretofore is perhaps sufficient reason for burdening the literary world with yet another philosophical work [Chicanismo As A World View]. ${ }^{38}$

For Carranza a metaphysical responsibility exists among Chicanos. Carnalismo opens the door to understanding this ethical imperative. Choosing to adhere to principle is the first step in embracing this Chicano weltanschauung.

Other Chicanos express similar ideas. E. A. Mares, in his evaluation of Freire, provides an important addition to Carranza's philosophy by introducing the concept of play. Since beginnings and absolutes are not the issue, then fiesta and homo laudens become fundamental since they allow a playful and non-oppressive manner of experiencing the world. Unfortunately contemporary society has separated life from fiesta resulting in alienation. Mares believes that only the Chicano and Native American, among the citizens of the US, remain in contact with the spirit of play. "Chicanos do have...in their non-Western or Indian heritage...elements of play and fiestas which serve as a reminder that life is not and need not be a continual dreary pattern of alienation, noncreative work." 39

Alienation results in dehumanizing structures resting on the mystique of science. Freire's conscientizacion, Mares believes, breaks through this fog by raising questions and then posing an altemative course of action, a true praxis, toward self-determination and self-liberation. This praxis is tied to fiesta. 
[The] celebration of fiesta under adverse circumstances, may have a great opportunity...for initiating a process of humanization, of restoration of the unity of man and the world, and for the creation of life styles more suitable to a post-technological society. ${ }^{40}$

As Maria Lugones suggests in a later piece, knowledge and jugeatar need to work as one. ${ }^{41}$

Many writers employ various aspects of the ideas formulated by Romano, Carranza, Mares and others. None necessarily see themselves as part of a unified school or agenda. Rather they share a need to ground the quest for knowledge as well as knowledge of the Chicano. Jose Armas' quest to save Chicano cultural identity is one example. He argues that Chicanos are lost because "there is nothing to distinguish themselves as culturally different Chicanos." ${ }^{22}$ In order to maintain this identity and therefore establish a humanistic society, the Chicano must develop social responsibility, a doctrina de La Raza, and a process to incorporate all Chicanos. With this doctrina, Chicanos can promote their values, maintain their cultural identity, and use "them as ready-made alternatives to what the dominant society has."

La Doctrina de La Raza would be the abc's of Chicanismo. The different themes and concepts selected are those that are needed to maintain the essence of La Raza culture. It is important to understand that the culture is learned. No one is born with culture. They learn their cultural attributes. The doctrina program would teach and reinforce those elements of La Raza culture. ${ }^{43}$

In another piece Armas sees the family as the place to begin to formulate and sustain this doctrina.

I have suggested that the Chicano cultural concept of "La Familia" provides for us a ready-made base from which to build our emerging identity and a humanistic system. Idolizing philosophies of Che, Pancho Villa, Zapata are for the moment, and they serve their purpose, but for a lasting and sane foundation for a humanistic way of life, we must look to our 'Familia.' The goals are for a foundation of brotherhood, a respect for people, a defense of the family that keeps us spiritually alive and a compatible attitude toward the land the keeps us physically alive. ${ }^{44}$

Many essays in De Colores: Journal of Emerging Raza Philosophies, edited by Armas, parallel these ideas. ${ }^{45}$ 


\section{Perspectivist Chicano Studies as Academic Project}

In the early 1970s, a few Chicano academics questioned the emerging empiricism in Chicano Studies. Influenced by Mexican and Chicano(a) thinking as well as debates in Western Marxism and developments in European philosophy, these scholars endeavored to present an alternative vision. While most of these writers did not necessarily recognize such a project, it is clear, some twenty-five years later, that their work presented a rejection of developing Empirical Chicano Studies and instead called for a different academic project.

The writings of some early Chicano literary critics allow us to explore a manifestation of Perspectivist Chicano Studies. Juan Rodriguez and Carlos Zamora argue that the "uniqueness" of the Chicano experience and identity together with humanism and praxis is the engine behind Chicano literature. Zamora points out that the praxis of humanism must be understood as a political act and therefore as the only salvation from "las fuerzas de la deshumanizacion (the forces of dehumanization)," las "cosificacion (reification)," and "la enajenacion del hombre (the alienation of man)." Therefore the artists' humanist praxis is a necessary aspect of the liberation of humanity. Segade adds that this praxis constructs the Chicano. "Chicano is a synthesized reality that [has] to be recognized and affirmed by those who [are] aware of living it." 46 Chicano literary criticism rooted in a Chicano perspective born from his living experience is an essential part of the political battle for self-determination and liberation. ${ }^{47}$

Juan Rodriquez's early essays articulate this vision. The growing consciousness of the Chicano, he starts, demands self-determination. The Anglo separates the Chicano from his history, culture and raison d'etre leaving him "en el mundo vertiginoso del enajenamiento (in the fluid world of alienation)." 48 The Chicano writer returns to this "awareness" 49 that is at the heart of Chicano literature.

He aqui el postulado basico de toda la literatura chicana: testimonear la vida particular $y$, por consiguiente, universal del chicano para asegurarle su sitio correspondiente en la familia de la raza humana, sitio que le pertenece por derecho propio, no divino, ni diabolico.

(Here is the basic postulate of all Chicano literature: to give testimony to both the particular and consequently the universal life of the Chicano, in order to assure [his] corresponding place in the family of the human race, a place that [he] earned by [his] own right. $)^{50}$ 
The artist is able to give the particularities of the Chicano being, especially in relationship with the long struggle against Anglo society. This process breaks the alienation that denies his being. To support his point, Rodriguez turn to Rivera's... Y no se lo trago la tierra. Rivera's novel reveals "momentos reveladores en la vida de un pueblo en lucha con su circumstancia y consigo mismo (moments in the life of a people in struggle with their circumstances and themselves)." ${ }^{51}$ In this manner, it restores the Chicano to his place in the continuum of humanity.

Raymond Rocco's essays present another example of academic Chicano perspectivism. He formulates a critical position for Chicano researchers. Scholars uncritically accept, Rocco begins, given concepts or theories as universal. Using Romano's and Deluvina Hernandez's critique of sccial scientists, Rocco turns to see what alternatives might exist to traditional social science.

The point is that there are many dimensions of "reality" that we never become conscious of. Our use of concepts, our designation of certain phenomena as "facts," really depends on those aspects of the culture which are emphasized as significant, which is ultimately determined by normative criteria. ${ }^{52}$

For Rocco knowledge is not singular nor homogeneous. "If we are to take the role of scientist seriously, then we should be dedicated to the search for as many forms of knowledge as possible." Perspective can provide alternative orientations that generate different research programs. Rocco concludes in his Aztlan essay that "[o]ne of the perspectives we must establish is one based on the experience of people who live in Mexican American community." 53

But Rocco is unsatisfied with this possible conclusion. It is insufficient to merely assert the need to base a perspective on a group's experience. In a later piece for the Western Political Quarterly he returns to the importance of clarifying one's theoretical position. He begins with a critique not only of social scientists' research but of social science in general, now grounding his discussion in critical theory.

They [critical theorists] argue that the majority of theorists and researchers have not recognized that the practice of social science rests on a substructure which is essentially philosophical or theoretical in nature and that any analysis of specific frameworks and methodologies must be firmly rooted in a knowledge of the more basic commitments made at the ontological, epistemological, and logical levels... . ${ }^{54}$

Traditional social science reifies data by abstracting it from relations that provide meaning and significance; it distorts reality. For this reason, 
one must be clear what one is doing and why, if not, consciously or not, one accepts the assumptions of social science-objectivity, facts, and truth. It is through praxis in the world that we come to understand knowledge claims.

Chicano scholarship, attuned to the Marxist, Cultural Nationalist, and Internal Colonialist models, seeks to explain the patterns of domination through structural terms. This, Rocco argues, emphasizes one realm of activity and therefore exhibits a reductionist tendency. One can overcome these limitations by translating issues into a theoretical complex defined by critical theory and praxis. Arguing through Leopoldo Zeas' writings, ${ }^{55}$ Rocco notes that the role of the intellectual is to mediate between philosophy and history. This mediation aims at the liberation of la persona resulting in emancipation from domination. It is by interrogating the "concreteness of historical experience" that we come to self-consciousness. "For philosophy to be philosophy it must achieve consciousness; thought which does not recognize its own circumstances does not reach self-consciousness." ${ }^{26}$ These conditions oblige one to practice responsibility. One can imply from Rocco's reading of Zea that just like the "authenticity of Latin American philosophy develops when it begins to assess its circumstances from the perspective of the colonized," so the Chicano will become subject when it acts in the world as self-consciousness. ${ }^{57}$

Perspectivist Chicano Studies, however, as a field, did not survive well in the academy. At one level, the university, especially the research institutions, set the conditions that made this controversial style of intellectual endeavor ineffectual. As the student protests died down, the limited space initially allowed to non-traditional approaches was further restricted. On another level, the system began to devour its opposition. "Chicano Studies have been absorbed. A traditional strategy of the majority system is to get hit, draw back and then devour whatever is hitting it." 58 In this situation, Empiricist Chicano Studies is simply more malleable to the institution. In this atmosphere, Perspectivist Chicano Studies breaks up into different directions losing its already limited cohesion and unity. ${ }^{59}$

\section{A Search for Alternative Pathways}

For some Chicanos their experience in institutions of higher learning left little hope for developing a radical and critical perspective within the academy. At best Chicano Studies might help students survive the institution, but one could not expect permanent change. Risco writes about this experience at Fresno State College.

[Y]ou cannot change the system using the system's tools. All you can do is patch up holes. There's is no such thing as a 
neutral education. It's all political... . No amount of Chicano Studies or La Raza Studies is going to change the system's master plan. But maybe Chicano Studies helps Chicanos while they are on those campuses. ${ }^{60}$

The answer, Risco concludes, is to develop alternative counter institutions.

Of the many alternative institutions that have appeared, the most interesting is La Academia de la Nueva Raza directed by Tomas Atencio. $\mathrm{La}$ Academia begins from the premise that "education has bypassed La Raza; that the value system underpinning the body of knowledge available to some of us in the course of our education is a foreign one."61 So where does one go from here? One heeds the "oro del barrio (the gold of the barrio)," the accumulated popular knowledge of the Chicano communities-not just of the past but of the present as well. From this oro "La Academia proposes to compile a philosophy"62 to use "life experience to build the body of knowledge from which people learn." ${ }^{\prime 3}$

The preceding argument is sufficient for us to demand a body of knowledge that embodies the Chicano experience. This dictates our tasks: we must dig into our past literature, our folklore, our history which is mostly oral; we must venture into areas related to the social and behavorial sciences and identify individuals and social behavior patterns that may reflect the Chicano experience as we struggle for survival. ${ }^{64}$ Therefore, Atencio is critical of the alternative schools that merely mirror the traditional system. Rather we must build a body of knowledge from La Raza experience and create a learning experience through dialogue-his famous resolana.

Another direction that Perspectivist Chicano Studies develops is in a certain style of community service. These perspectivist writers formulate an interactive approach in which the community is not transformed into object or problem. Their aim is to push the academy to open their intellectual space to a different style of logic, a logic that starts with the living experience of people who become the subject as well as object of research. By grounding research on lived experience, Chicano scholars confront social science. This is more than a conflict between macro and micro or quantitative and qualitative sytles of research.

Hijos del Sol, for instance, developed a program for children, youth, and their families based on their experience: "A person's own life experiences comprise a knowledge base." ${ }^{.65}$ In this way we escape the chronic pattern of "EI No." "EI No" explains the dynamic by which society negates personal and group power manifesting itself in the words "no puedo (I can't)."66 What we encounter is the development of "razalogia." Later, Martinez and Vargas expanded on this idea of community learning process. "Razalogia has evolved out of the attempt to conceptually describe our approach for developing knowledge 
that heals, liberates and transforms." ${ }^{7}$ This "transformative learning" is the process of creating knowledge "partial to the needs and well-being of the community." What these individuals, who entered community services, learned from the academy had to be completely reconceptualized. "Having critiqued the field of psychology as inapplicable to an understanding of the Chicano reality, we eventually agreed that understanding the "Chicano experience" required sharing from our personal lives."68

Thus activity in community services, like La Clincia del las Raza, lead to razalogia-knowledge for Raza by Raza. In this process of learning from our experience, we move away from "no puedo"-an internal devaluation of self-to a reconceptualization of our power. At this stage, the Chicano community needs self organization: "[l] recognized that our communities require, not merely more professionals or services, but an ideology and activism that seek radical change in our social systems." 69 As razalogia develops, it leads to the formation of "progente/provida" network. Clearly the application of razalogia "must be extended beyond the work arena to one's family and community life." By this point razalogia shifts from its Chicano perspective and becomes more appropriately "an approach of transformative learning guiding a conscious community knowing toward advancing human/social transformation." ${ }^{" 0}$

\section{Perspectivist Chicano Studies on the Essentialist Edge}

Perspectivist Chicano Studies could easily cross over into essentialism. ${ }^{71}$ Dan Porath, for example, argues that the philosophy of perspectivism is attractive to the "Latin mind" given the Mexican/Chicano tragic sense of life. Drawing on his reading of Unamuno, Oretga y Gasset, Romanell, and pre-Columbian Indian mysticism, he believes that the Mexican is born an existentialist. "Certain 'feelings' are suggested in the deep mysticism of the pre-Conquest world as well as the particular history which Latin America has experienced." ${ }^{2}$ Though he notes the role of experience in forming a philosophy of life, he continuously roots this vision in the nature of the Mexican.

What had been tried then, in attempting to impose the empirical, scientific approach on the Mexican [i.e. positivism], was not to allow a system to develop from the Mexican's own experience, but as an attempt to assimilate the Mexican to an outside source. And the Mexican was too Mexican to buy it. ${ }^{73}$

The true Mexican, Porath insists, is an existential man.

When he turns to Chicanos, he encounters the same spirit in this population. We can trace this from the pachuco to Cesar Chavez, "Corky" Gonzalez, and Romano. Porath distinguishes his understanding of Chicanismo from what one finds in academic Chicano Studies. 
"Very little of what was presented to the Chicano had its origins in the barrio, primarily because most of these [C]hicano scholars were not barrio oriented-they had escaped long ago and had become successful in the 'mainstream' culture." ${ }^{74}$ Chicanismo, Porath notes, is about the barrio, cultural revolution, and creating a new social being. Most importantly, Chicanismo is about existing in the here and now. As the initial statement of Con Safos states: "It is rather an attempt at expressing the entire spectrum of feelings that are the soul of the barrio."75 One can see an unresolved tension in some perspectivists between essentialism and the desire to ground this perspective in Chicano or Mexican experience.

One theme among perspectivists writers is the Chicanos(as)' native past. This often suggests an essentialist interpretation. For instance at the same time razalogia moves toward transformative praxis, Vargas returns to a romanticized notion of our native past. ${ }^{76}$ A. Solis, who influences razalogia formation, is another example of this return to our native roots-not solely in a racial or cultural sense but also in its spiritual significance. "Chicano cultural values are recognized to be within the realm of the Chicano or Native American Spirit...."77 "It is a shared psychological spiritual force. At that point we begin to see-in Tloque, in Nahuaque. "The spirit of Unity-Togetherness, as we practice it, begins to emerge." ${ }^{18}$ Where does this come from? Solis points to our native past, to our "tatas." "We "We are first of all and at the very core or root of our psyche and spirit, Native-Americans of any one or some Mexican Indian tribe(s)." ${ }^{80}$ From here we draw our Mexicano-Chicano values, especially harmony and community and the quest for land. ${ }^{81}$

For some Chicanos, the native past governs their vision of the world. These authors believe that their true Chicano being is tied to that indigenous past/present. What stands out from these essays is the role of culture and spirituality. They believe that they can revive the cultural values that were "lost" after 1848. The Chicano, Alarcon argues, must return to Mother Earth. It is spirituality that is at the heart of Chicanismo; the barrio is the vital center of Chicanismo as the home of this native spirit. "The main awareness of the movimiento has its base in the philosophical attitude that the total unity of the Chicano is the principal spiritual force and that the barrio is the center of the "living culture. ${ }^{n 82}$ We must rescue these essential values from Anglo materialist hands. One need only glimpse through much of early Alurista poetry or Valdez's meditations to sense this view. For example in an essay in De Colores, Alurista draws a sharp contrast between the Indian world or harmony and balance and the Anglo world. ${ }^{83}$ Another example is Valdez' Pensamientos serpentinos. ${ }^{84}$ Chicano being, they imply, is decided by this native past. ${ }^{85}$

This concern with our indigenous heritage has lead to an enormous outpouring of literary and intellectual work. We could not sepa- 
rate early Chicano Studies from the quest of the Chicano's(a's) real and mythic historical identity. The use of Indian motifs, Klor de Alva notes, is due to the preoccupation with the search for identity, an appeal to the great indigenous civilizations of the past as a source of pride, and a quest for a symbolic nexus that can link all Chicanos despite their heterogeneity. In many ways the quest for Aztlan is about this past and our connection to it. When we think of the early poetry and art of the Chicano Movement we cannot escape these motifs and symbols. And yet its meaning and importance varies in our communities. Note how the Teatro Campesino and Luis Valdez reframe "Corky" Gonzalez' I am Joaquin by bringing out the indigenous elements more than a reading of the piece might have done. All readings of this native heritage are equivocal. Not all perspectivists essentialize their conceptualization of the native past/ present.

Some Chicano writers, for instance, recall our native past in order to challenge Western epistemology-avoiding essentialist claims. Faced with the social science leviathan, how do we challenge and offer a counter epistemology? Francisco Vazquez asserts the need to utilize epistemological alternatives such as the Aztec search for truth. ${ }^{86}$ Raymond Padilla expands on this notion by acknowledging our Western heritage (Socratic, Christian, Hegelian, Marxist, Buberian) but regards it as only part of our intellectual tradition. Therefore we need to look toward our indigenous heritage and legacy, not to live in or reestablish this past but to retake our legitimate heritage. ${ }^{87}$ With these resources, we can engage in "chicanizaje" 88 or "chicanology." ${ }^{89}$ To other Chicanos, this awareness of our past opens the possibility of "la vida nueva." 90 These readings represent perspectivist vision of our past. The goal is not to resurrect some real historic past but to begin our epistemological transformation from our situation in the world, our becoming, by taking possession of our past and identity.

\section{CONCLUSION}

In this essay I trace the genesis and development of one possible style of doing Chicano Studies. Beginning with the work of Romano and Carranza, I draw attention to their perspectivist epistemology. This approach to knowledge privileges the position and context of the knower. This stress on being is reflected in concepts like Chicanismo, carnalismo, and humanism that can produce a culture that makes visible humanity-especially in light of the perceived failures of the Anglo value system.

In the academic world, few have ventured into this style. Most examples could be found in the field of literary criticism. In the academy the struggle against alienation could be accomplished at both the situated position of the Chicano and the universal level of humanity. I use 
Juan Rodriguez's essays as an example. From the angle of social science I turn to the writings of Raymond Rocco who presents a critique of instrumentalist knowledge followed by a call to draw a perspective from the experiences of the Chicano community. In this way the scholar becomes an active participant, to recall Zea, in the liberation of la persona and thereby humanity.

Unfortunately, Perspectivist Chicano Studies never became a viable choice among research agendas. Therefore the only real option, according to Risco, was to abandon the academy if one desired change. In this essay, I look at a couple of alternative pathways that some Chicanos choose: Atencio's La Academia de la Nueva Raza and the community project of Hijos del Sol.

Clearly at the center of this perspectivist project is self-consciousness. A danger, however, exists in trying to ground this self-consciousness. It is easy to step from a perspectivist analysis over to essentialism and nativism. Perspectivist thinkers often drew links to the Chicano native past in order to emphasize the existence of alternative world views. Some could interpret this as creating a Chicano-centric world view, but at this point Perspectivist Chicano Studies had faded.

By the mid 1980s, Perspectivist Chicano Studies as an alternative style of Chicano knowing had evaporated. The lack of an established base in the academy undercut the development of a core of perspectivist scholars. Furthermore the rise of structuralism, poststructuralism, feminism, postmodernism, neo-marxism, and queer theory contested the philosophical ground of the perspectivist camp. But the most damaging impact was the exclusionary politics of empirics. The end result was to vanquish Perspectivist Chicano Studies as a viable alternative.

Nevertheless in challenging Empirical Chicano Studies, perspectivists demonstrated the limitations of this dominant view. The empirics could not escape the partriarchal, logico-deductive, and instrumentalist reasoning that is at the core of the U.S. academy. While empirics may not have achieved all their institutional goals, they did find an intellectual space in the academy. Ironically just as Perspectivist Chicano Studies faded, new contestants arose to critique Empirical Chicano Studies. These new provocations took a variety of shapes, from the radical epistemological attacks by queer theorists and postmodernists to more moderate criticism of the exclusionary politics of empirics by multiculturalists, feminists, and those interested in Latino and/ or American Studies. These issues, however, must be left for another time. 


\section{NOTES}

II would like to thank Richard Chabran, Mary Romero, Eric Margolis, Ray Rocco, Angelina Soldatenko, and the readers of ESR for their intellectual input. I also want to thank Chicano Studies at ASU for reminding me that exclusionary politics is alive and well.

2I have retained "Chicano" since its male usage reflects the gendered politics and epistemology of the movimiento, particularly in the academy. This will also help us discern the epistemic break of Chicana feminist though.

"I have had a difficult time naming this tradition. Initially I called it "Existential Chicano Studies." But readers of earlier versions of this project felt that this term unnecessarily introduced the long history of phenomenology and existentialsim into this discussion. While some of these early Chicano(a) thinkers may have accepted this baggage, others would not have. I found perspectivist much more acceptable. In this manner the influence of Ramos, Romanell, Paz, and Ortega y Gasset can be more fully appreciated (Eliu Carranza, Pensamientos on Los Chicanos. Second edition. (Berkeley: California Book Co., 1971) and Dan Porath, "Chicanos and Existentialism," De Colores 1:2 (1974), 13).

${ }^{4}$ Patrick Romanell, Making of the Mexican Mind: A Study in Recent Mexican Thought (Lincoln: University of Nebraska Press, 1952).

${ }^{5}$ Romanell, 161. Romanell's citations are from the English translation of Ortega y Gasset's El tema de muestro tiempo (Madrid: Revista de Occidente, 1923).

${ }^{6}$ Romanell, 161.

'Octavio Ignacio Romano-V., "Minorities, History, and the Cultural Mystique," El Grito: A Journal of Contemporary Mexican-American Thought 2:1 (1967), 7; Octavio Ignacio Romano-V., "The Anthropology and Sociology of the Mexican-American: The Distortion of Mexican-American History," El Grito: A Journal of Contemporary Mexican-American Thought 2:1 (1968), 23.

${ }^{8}$ Octavio Ignacio Romano-V., "The Historical and Intellectual Presence of Mexican-Americans," El Grito: A Journal of Contemporary MexicanAmerican Thought 2:2 (1969), 37.

'Octavio, Ignacio Romano-V., "Book Review of North from Mexico: The Spanish Speaking People of the United States," El Grito: A Journal of 
${ }^{10}$ Octavio Ignacio Romano-V., "Social Science, Objectivity, and the Chicanos," El Grito: A Journal of Contemporary Mexican-American Thought 4:1 (1970), 5-6, 11-13.

"Romano, "Social Science," 12.

${ }^{12}$ Refugio I. Rochin, "The Short and Turbulent Life of Chicano Studies: A Preliminary Study of Emgering Programs and Problems" Social Science Quarterly 53:4 (1973), 888.

${ }^{13} J u a n$ Gomez-Quinones, Mexican Students Por La Raza: The Chicano Student Movement in Southern California 1967-1977 (Santa Barbara: Editorial La Causa, 1978), 8.

${ }^{14}$ Chicano Coordinating Council on Higher Education, EI Plan de Santa Barbara: A Chicano Plan for Higher Education (Santa Barbara: La Causa Publications, 1970), 16; Carlos Munoz, Youth, Identity, Power: The Chicano Generation (London: Verso, 1989), 138-139; Gomez-Quinones, Mexican, 14.

${ }^{15}$ Reynaldo Macias, Juan Gomez-Quinones, Raymond Castro, "Objectives of Chicano Studies," Epoca 1:2 (1971): 32.

${ }^{16}$ Macias, 31-33.

${ }^{17}$ Macias, 32

${ }^{18}$ Ignacio Garcia's recent writings reassert this empiricist vision. His analy sis of the development of Mexican American intellectuals ignores individuals who did not share or belong to the empiric school. For Garcia there was and can only be one Chicano Studies-as presented in EI Plan de Santa Barbara - Ignacio M. Garcia, "Juncture in the Road: Chicano Studies Since 'El Plan de Santa Barbara"' in Chicanas/Chicanos at the Crossroads: Social, Economic, and Political Change, David Maciel and Isidro Ortiz, eds. (Tucson: University of Arizona Press, 1996), 182. Potential competitors to Empirical Chicano Studies are dismissed as "disciplines of anarchy" or in the present as various manifestations of "post modern sectarianism" - Ignacio M. Garcia, Chicanismo: The Forging of a Militant Ethos among Mexican Americans (Tucson: University of Arizona Press, 1997), 61; Garcia, 1996, 189). Even the serious critique of Chicanas is dismissed as, at best, premature and, at worst, separatist. But the Movement could not help but challenge patriarchy through its liberation rhetoric and through the opportunity it gave women 
my emphasis) to become involved in protest activities (Garcia, 1997, 64). Nevertheless, Garcia is forced to recognize the validity of Chicana assessment of the movimiento but then concludes, at the same time, that concentration on the Chicana experience reduced Chicanas influ (ence in the Chicano community (Garcia, 1997, 110). For Garcia the solution to the current crisis in Chicano Studies is to return to the original program for Chicano Studies as established in El Plan de Santa Barbara (Garcia, 1996, 195). For a critique of Garcia see Lorena Oropeza, "Making History: The Chicano Movement," JSRI Occasional Paper Series Number 17 (East Lansing, MI: Julian Samora Research Institute, Michigan State University, 1997), 1-26.

${ }^{19}$ Thomas Martinez, “Chicanismo," Epoca 1:2 (1971), 35

${ }^{20}$ Martinez, "Chicanismo," 38.

21Martinez, "Chicanismo," 39.

22Martinez, "Chicanismo," 40.

${ }^{23}$ Celia Medina, Chicanos, Existentialism and the Human Condition (San Jose: Marfel Associates, 1974), 34.

24Juan Gomez-Quinones, Chicano Politics: Reality and Promise 19401990 (Albuquerque: University of New Mexico Press, 1990), 104-105.

${ }^{25}$ Theresa Aragon de Shepro, Chicanismo and Mexican American Politics (Seattle: Centro de Estudios Chicanos, 1971), 1; Alfredo Cuellar, "Perspective on Politics" in Joan W. Moore, ed. Mexican Americans(Englewood Cliffs: Prentice-Hall, 1970), 149.

${ }^{26}$ Aragon, Chicanismo, 12.

${ }^{27}$ Adrian Vargas, "Carnalismo," Chilam Balam 1:3 (1972), 17.

${ }^{28}$ Nephtali De Leon, Chicanos: Our Background and Our Pride (Lubbock: Trucha Publications, 1972), 4.

${ }^{29}$ Cuellar, "Perspectives," 153.

30The relationship between Chicanismo and feminism is problematic. Alma Garcia, for instance, notes that many Chicanas raise a "collective feminist challenge" to the sexism and male domination in both the movimiento and Chicanismo. This criticism came from women's experience with the contradictions of Chicanismo. "From their nationalist base, 
these Chicana activists began to evolve also as feminists." - Alma Garcia, Chicana Feminist Thought: The Basic Historical Writings (New York: Routledge, 1997), 3. Feminism appears, in Garcia's research, as a break from Chicanismo. Ana Castillo takes a different view. She begins by calling attention to the works of Chicanas that examined the racism, sexism, and sexist racism that socially and economically oppressed them; especially the writings of Ana Nieto Gomez [Ana Castillo, Massacre of the Dreamers: Essays on Xicanisma (Albuquerque: University of New Mexico Press, 1994), 33]. In particular, Castillo calls attention to the "philosophy of the male-dominated Chicano Movement" (53). However Castillo is attracted to the cultural and nationalist attributes of Chicanismo. Castillo argues that women can "assert a pride in their ethnicity" accepting a form of cultural nationalism without falling into patriarchy (95).

${ }^{31}$ Eliu Carranza, Pensamientos on Los Chicanos: A Cultural Revolution (Berkeley: California Book Co., 1969), 4.

${ }^{32}$ Carranza, Pensamientos, 16.

${ }^{33}$ Carranza, Pensamientos (second edition), 21.

${ }^{34}$ Elihu Carranza, Chicanismo: Philosophical Fragments (Dubuque: Kendall/Hall Publishing Co., 1978), 129

${ }^{35}$ Carranza, Pensamientos (second edition), 17.

${ }^{36}$ Carranza, Pensamientos (second edition), 18.

${ }^{37}$ Carranza, Chicanismo, 131.

${ }^{38}$ Carranza, Chicanismo, 132.

${ }^{39}$ E.A. Mares, "The Fiesta of Life: Impressions of Paulo Freire," EI Cuaderno, 3:2 (1974), 6. Mares adds later on "The idea of mirth, humor, playfulness as an integral part of life, as an on-going fiesta, as a graceful and joyful acceptance of human folly, is as old as the Totonac Period, even older, according to Octavio Paz, and as recent as the insights of a Yaqui man of knowledge" (Mares, "Fiesta," 10).

40Mares, "Fiesta," 14.

${ }^{41}$ Maria Lugones, "Playfulness, 'World'-Travelling, and Loving Perception" in Gloria Anzaldua, ed. Making Face, Making Soul: Haciendo Caras (San Francisco: Aunt Lute Books, 1990), 390-402. 
42Jose Armas, "Doctrina de La Raza," De Colores: Journal of Emerging Raza Philosophies, 1:2 (1974), 43.

${ }^{43}$ Armas, "Doctrina," 44.

${ }^{44}$ Jose Armas, "La Familia de la Raza," De Colores: Journal of Emerging Raza Philosophies 3:2 (1976), 54.

${ }^{45}$ Clearly Armas' work reflects a patriarchal world. His definition of la raza, chicanismo, la familia are gendered; they are defined through his male vision of the world. The same, of course is true in the statements we find in Carranza and others. Both perspectivists and empiricists privilege their male position-politically and intellectually.

${ }^{46}$ Gustavo Segade, "Toward a Dialectic of Chicano Literature," Mester 4:1 (1973), 4; Gustavo Segade, "An Introduction to Floricanto" in Alurista et al (eds) An Anthology of Chicano Literature (Los Angeles: University of California Press, 1976), 3.

${ }^{47}$ Jose Armas, "Introduction" in Jose Armas et al (eds) Flor y Canto IV and V (NP: Pajarito Publications, 1980), 10; Juan Rodriguez, "Donde Esta la onda?" Revista Chicano-Riquena 3:3 (1975), 3-5; Juan Rodriguez, "La busqueda de identidad y sus motivos en la literatura chicana" in Francisco Jimenez (ed) The Identification and Analysis of Chicano Literature (New York: Bilingual Press, 1979), 170-178; Carlos Zamora, "Humanismo y Praxis Artistica," Mester 4:1 (1973), 3.

${ }^{48}$ Rodriguez, "La busquenda," 7.

${ }^{49}$ Consecuentemente, un awareness, un estar consciente de si mismo, de su circunstancia respecto a la de los otros, un reconocimiento de su otredad, son el sine que non de la busqueda de identidad del chicano en la literatura (Consequently, an awareness, a consciousness of oneself, of one's circumstances in reference to others, a recognition of otherness, are the sine que non of the search for chicano identity in literature)" (Rodriguez, "Donde”, 162).

${ }^{50}$ Rodriguez, "La busqueda," 8.

51 Juan Rodriguez, "Aceramiento a cuatro relatos de ... Y no se lo trago la tierra," Mester 5:1 (1974), 16.

${ }^{52}$ Raymond Rocco, "The Chicano in the Social Sciences: Traditional Concepts, Myths, and Images," Aztlan: Chicano Journal of the Social Sciences and Arts 1:2 (Fall 1970), 92. 
${ }^{53 R o c c o, ~ " T h e ~ C h i c a n o, " ~} 92$ and 93.

${ }^{54}$ Raymond Rocco, "A Critical Perspective on the Study of Chicano Politics," Western Political Quarterly 30:4 (1977), 562.

${ }^{55}$ For Romanell, Zea is another "neo-Orteguian 'circumstantialist"' (1952, 176).

${ }^{56}$ Raymond Rocco, "Marginality and the Recovery of History: On Leopoldo Zea" Canadian Journal of Political and Social Theory 4:3 (1981), 43.

${ }^{57}$ Rocco, "Marginality," 43.

${ }^{58}$ Paul Sanchez, "Memoirs of a Chicano Administrator," in Parameters of Institutional Change: Chicano Experiences in Education (Hayward: Southwest Network, 1974), 53.

${ }^{59}$ Chicano(a) social scientists created NACS (National Association for Chicano Studies) in 1972 as an organization to unite Chicanos(as) in the academy in order to foster a Chicano agenda. While perspectivists participated in this organization, NACS echoed the empiricist agenda. At an initial meeting held at New Mexico Highlands University in 1973, the directions of Chicano social science were set. First, social science research by Chicanos must be problem-oriented; it was to be committed scholarship. This would satisfy the "activist" character of Chicano Studies. Moreover, social science research was to be interdisciplinary in nature. Third, Chicano practice of social science must break down barriers between research and action. Fourth, Chicano social science must be highly critical and rigorous. Lastly, Chicanos must not limit the scope of their research - Reynaldo Flores Macias ed. Perspectivas en Chicano Studies (Los Angeles: UCLA Chicano Studies Center, 1977), 214-216). The form of this new organization was to be in keeping with the philosophy and direction of the new Chicano social science. Munoz adds that an "[a]greement was reached that traditional social science was to be discouraged within the proposed association in favor of more critical analysis as afforded by the internal colonial and Marxist class analysis" - Carols Munoz, "The Quest for Paradigm: The Development of Chicano Studies and Intellectuals" in Mario Garcia and Francisco Lomeli, eds. History, Culture, and Society: Chicano Stuides in the 1980s (Ypsilanti, MI: Bilingual Press, 1983), 30-31. In the third annual conference held in 1975, a session was held on "Chicano Social Science: The Ethnics and Politics of Research" - ElMirlo Canta de Noticatlan: Carta Sobre Chicano Studies 2, 9 (1975), 2. All of this parallels the direction of Aztlan and, of course, reflects the inspiration of El Plan. 
${ }^{60}$ Eliezer Risco, "Before Universidad de Aztlan: Ethnic Studies at Fresno State College," in Parameters of Institutional Change: Chicano Experiences in Education, 1974, 46.

${ }^{61}$ Tomas Atencio, "La Academia de la Nueva Raza: Su Historia" El Cuaderno 1 (1971), 6.

62Tomas Atencio, "La Academia de la Nueva Raza: El Oro del Barrio" El Cuaderno 3:1 (1973), 6.

${ }^{63}$ Atencio, $1971,7$.

${ }^{64}$ Tomas Atencio, "La Academia de la Nueva Raza: Sus Obras" El Cuaderno 2:1 (1972), 7.

${ }^{65}$ Samuel C. Martinez and Hijos de Sol staff, Hijos del Sol: An Approach to Raza Community Mental Health (Oakland: Casa del Sol, 1981), 19.

${ }^{66}$ Samuel C. Martinez and Roberto Vargas, Razalogia: Community Learning for a New Society (Oakland: Razagente Assoc., 1984), 78.

${ }^{67}$ Martinez and Vargas, Razalogia, 2.

${ }^{68}$ Martinez and Vargas, Razalogia 8.

${ }^{69}$ Martinez and Vargas, Razalogia, 16.

${ }^{70}$ Martinez and Vargas, Razalogia, 22 and 26.

${ }^{71}$ Essentialist arguments can be found in all styles of Chicano Studies. How we deal with who we are lead to discussions that could essentialize concepts like race, nation, gender, sexual orientation, color, and class. We attribute characteristics to these particular notions ignoring their historical and social nature. Given the intensity of political and social battle, this was possibly unavoidable. I do not want to trace or search out all these incidents of essentializing in Chicano Studies.

${ }^{72}$ Porath, "Chicanos," 13.

73Porath, "Chicanos," 11.

${ }^{74}$ Porath, "Chicanos," 18.

${ }^{75}$ Con Safos 1:1 (1968): 1. 
${ }^{76}$ Roberto Vargas, Provida Leadership: A Guide to Human/Social Transformation (Oakland: Razagente Assoc., 1985), 6.

${ }^{77}$ A. Solis, "Chicano Mental Health: Introduction to Chicano Values," Calmecac (Verano 1980), 52.

${ }^{78}$ A. Solis, "Traditional Chicano Centering," Calmecac (Primavera 1982), 18.

${ }^{79}$ Ana Luisa Bustamante, "La Ciencia en la Tradicion," Calmecac (Primavera 1982), 11-17.

${ }^{80} \mathrm{~A}$. Solis, "Chicano Values: Living in Balance," Calmecac (Primavera 1982), 30.

${ }^{81}$ A. Solis, "Chicano Values_Part III," Calmecac (Invierno 1984), 16-20; Ana Luisa Bustamante, "Spiral of Cultural Identity Development," Calmecac (Invierno 1984); L.K. Banas, "Donde Estas? Conflicts in the Chicano Movement," Caracol 3:11 (1977) 15-77; L.K. Banas, "Donde Estoy?" Calmecac (Primavera 1981); Jose Castorena, "La Raza Nueva: The Fire that Does Not Consume Itself," Regeneracion 1:3 (1979), 1-2. "On the Black or White Revolutionary's Relation to the Chicano Struggle," La Causa 2:1 (1971). The marxist response to these arguments could be very condescending and rough. Recall C. G. C.'s response to Banas in Caracol-"Carta Abierta to L.K. Banas," Caracol 4:2 (1977), 18-20.

82Justo S. Alarcon, "Historical and Cultural Concepts of Chicanismo." Unpublished paper. Chicano Collection, Arizona State University, 1973, 23.

${ }^{83}$ Alurista, "The Chicano Cultural Revolution," De Colores: Journal of Emerging Raza Philosophies 1:1 (Winter 1973), 23-33.

${ }^{84}$ Luis Valdez, Pensamiento Serpentino: A Chicano Approach to the Theater of Reality (NP: Cucaracha Publications, 1973).

${ }^{85} \mathrm{Klor}$ de Alva argues that this indigenous interest began to fade by the mid 1980s. Even Alurista became less indigenista in his writing. "Interest in Mesoamerica in slowly being eroded as questions of identity, pride, and political unity are finding their answers more within a Chicano than a Mexican context" (J. Jorge Klor de Alva, "California Chicano Literature and Pre-Columbian Motifs: Foil and Fetish," Confluenica 1:2 (1986), (19). Klor de Alva jumped the gun. For in fact we are witnessing a revival of native spirituality and motifs. We should recognize that major political, ideological, and even interpretive differences exist between the use of indigenous symbols and spiritutality in the early Chicano Move- 
Ethnic Studies Review Vol. 19, No. $2 \& 3$

ment and their current appropriation by some Chicano groups.

${ }^{86} \mathrm{Francisco} \mathrm{H}$. Vazquez, "Aztec Epistemology," El Grito 5, 4 (Summer 1972), 74-79. In its formative period Chicano Studies, Vazquez develops, dealt primarily with the critical lack of knowledge about the Chicano population. Recently the focus has expanded to include research on the process by which certain bodies of knowledge are excluded from the established curricula - Francisco Vazquez, "Chicano Studies and a Liberal Arts Education," Somos 1:2 (June-July 1978), 37.

${ }^{87}$ Raymond Padilla, "Freireismo and Chicanizaje" El Grito 6, 4 (Summer 1973), 79.

${ }^{88}$ Padilla, "Freireismo."

${ }^{89}$ Francisco H. Vazquez, "Chicanology: A Postmodern Analysis of Meshicano Discourse," American Perspectivism in Mexican Studies 3 (1992), 116-147.

${ }^{90}$ Federico Sanchez, "Looking Back on Chicano Thought," Con Safos 8 (1972), 39-42; Federico Sanchez, "Raices Mexicanas," El Grito del Sol 1:4 (1976), 75-87. 